\title{
GLUTATHIONE REDUCTASE, REDUCED GLUTATHIONE AND CERULOPLASMIN IN DIETHYLDITHIOCARBAMATE TREATED RATS
}

\author{
H. Ramachandra Prabhu, Vijaya Marakala
}

1. Professor, Department of Biochemistry, Srinivas Institute of Medical Science \& Research Centre, Mukka, Surathkal, Mangalore.

2. Assistant Professor, Department of Biochemistry, Srinivas Institute of Medical Science \& Research Centre, Mukka, Surathkal, Mangalore.

\section{CORRESPONDING AUTHOR}

Dr. H. Ramachandra Prabhu

Professor, Department of Biochemistry,

Srinivas Institute of Medical Science \& Research Centre,

Mukka, Surathkal, Mangalore

E-mail: hergaprabhu@rediffmail.com

Ph: 00919845531115

ABSTRACT: Intraperitoneal injection of rats with diethyldithiocarbamate $(1.2 \mathrm{~g} / \mathrm{kg}$ body weight) led to a maximum diminution of glutathione reductase at $12 \mathrm{hr}$ by $40 \%$ and $56 \%$ in liver and red blood cells respectively, with a gradual return to the normal level at $48 \mathrm{hr}$ after administration. Significant inhibition of reduced glutathione was also observed, which returned to normal at $48 \mathrm{hr}$ after administration. However, maximum decline in its content was at $12 \mathrm{hr}$ by $71 \%$ and $37 \%$ in liver and red blood cells respectively. A similar pattern was exhibited with respect to liver and serum ceruloplasmin in the diethyldithiocarbamate injected rats. It is possible that oxidant stress is developed in the rats by the administration of diethyldithiocarbamate with concomitant decrease in the activity of antioxidant enzymes and the other antioxidants such as reduced glutathione and ceruloplasmin.

KEYWORDS: Glutathione reductase, reduced glutathione, ceruloplasmin, diethyldithiocarbamate.

INTRODUCTION: Intraperitoneal injection of rats with diethyldithiocarbamate (DDC), a powerful copper chelator, causes decline in superoxide dismutase in various tissues of experimental animals. ${ }^{1,2}$ DDC administration to rats significantly decreased the cellular activity of selenium-dependent glutathione peroxidase. ${ }^{3}$ There are several metabolic processes which generate superoxide anion radical $\left(\mathrm{O}_{2}{ }^{-}\right)$in the respiring cells. ${ }^{4}$ If these radicals are not effectively removed, they are toxic to the cells due to their ability to promote lipid peroxidation $^{4,5}$ and to provoke the denaturation of certain enzymes. ${ }^{6}$ Superoxide dismutase, which catalyses the dismutation of $\mathrm{O}_{2}$ - is considered to be the essential enzyme in the defense against the toxic effects of $\mathrm{O}_{2}^{-}$. Maintenance of intracellular level of this enzyme is necessary to prevent free radical toxicity. In view of these reports, it was felt necessary to study the effect of DDC administration on the levels of glutathione reductase and reduced glutathione in liver and erythrocytes and serum ceruloplasmin of rats. This study is aimed at establishing the mutually supportive role of the antioxidant enzymes such as superoxide dismutase, glutathione peroxidase, glutathione reductase, ceruloplasmin and antioxidant such as reduced glutathione.

MATERIALS AND METHODS: CHEMICALS: Bovine serum albumin (fraction V) and 5, 5 dithiobis 2- nitrobenzoic acid were purchased from Sigma Chemical Company (St. Louis MO, 
USA). Diethyl dithiocarbamate was obtained from BDH Chemicals Ltd. (Poole, England). Oxidised glutathione and NADPH were purchased from CSIR centre for Biochemicals. All other chemicals used were commercial products of highest analytical grade available in India.

ANIMALS: Male albino rats (Wistar strain; 150-180 g) used in the present study were maintained on pellet diet and water ad libitum for 7 weeks. A group of 6 rats received a single dose of $0.5 \mathrm{ml}$ normal saline intraperitoneally (i.p.) and were sacrificed exactly $1 \mathrm{hr}$ after the injection. This group of rats was considered as control. A second group of 30 rats were injected (i.p.) with DDC $(1.2 \mathrm{~g} / \mathrm{kg})$ as has been reported earlier ${ }^{1}$. These rats in batches of 6 each were sacrificed successively at an interval of $1,6,12,24$ and $48 \mathrm{hr}$ after the injection. The experimental design has approval of Institutional Ethical Committee.

MODE OF SACRIFICE: Rats were sacrificed under ether anesthesia. They were bled by cardiac puncture and blood was collected using heparin rinsed syringes. Liver was quickly excised off, washed in sequence with saline, saline phosphate buffer $(10 \mathrm{mM}$, potassium phosphate buffer containing $0.15 \mathrm{M} \mathrm{NaCl} ; \mathrm{pH} 7.4$ ) blotted dry and stored at $4^{\circ} \mathrm{C}$. All the estimations were completed within $48 \mathrm{hr}$ of sacrifice.

PREPARATION OF TISSUE HOMOGENATES: Liver homogenates $(10 \% \mathrm{~W} / \mathrm{V})$ were prepared in potassium phosphate buffer $(10 \mathrm{mM})$ containing $0.15 \mathrm{M} \mathrm{NaCl}(\mathrm{pH} 7.4)$, using mechanical homogenizer. Unbroken cells and cell debris were removed by centrifugation at $700 \mathrm{~g}$ for 10 min using Remi C - 24 refrigerated centrifuge. The supernatant thus obtained was termed as tissue homogenate, was used for essay of reduced glutathione, glutathione reductase and ceruloplasmin.

PREPARATION OF HEMOLYSATE FOR GLUTATHIONE REDUCTASE: To $0.2 \mathrm{ml}$ of packed, saline washed erythrocytes, $4.8 \mathrm{ml}$ of distilled water was added and mixed. The supernatant obtained after centrifugation at $4^{\circ} \mathrm{C}$ was used immediately.

ASSAY OF GLUTATHIONE REDUCTASE ACTIVITY: The activity of glutathione reductase was determined by the procedure of Horn and Burns as given by Bergmeyer ${ }^{7}$. The cuvette contained $1.6 \mathrm{ml}$ of $0.067 \mathrm{M}$ potassium phosphate buffer ( $\mathrm{pH} 6.6$ ), $0.12 \mathrm{ml}$ of $0.06 \% \mathrm{NADPH}, 0.12 \mathrm{ml}$ of $1.15 \% \mathrm{G}-\mathrm{S}-\mathrm{S}-\mathrm{G}, 0.1 \mathrm{ml}$ of the tissue homogenate or hemolysate and water in a final volume of 2 $\mathrm{ml}$. The decrease in O.D. was recorded at $340 \mathrm{~nm}$ for 3-5 $\mathrm{min}$ in Spectronic 21 spectrophotometer. For each series of measurements, controls were done containing water instead of G-S-S-G. Under the conditions of the assay, NADPH dependent glutathione reductase activity was linear with time. The enzyme activity was expressed as nmoles of NADPH oxidized/min/mg protein.

ESTIMATION OF REDUCED GLUTATHIONE (GSH): The GSH content of erythrocytes and tissue homogenates was determined by the improved method of Beulteret $a l^{8}$. To $0.2 \mathrm{ml}$ of the packed erythrocytes or tissue homogenate, was added $1.8 \mathrm{ml}$ of distilled water and $3 \mathrm{ml}$ of the precipitating solution (1.67 gm of glacial metaphosphoric acid, $0.2 \mathrm{gm}$ of EDTA and $30 \mathrm{gm}$ of $\mathrm{NaCl}$ per $100 \mathrm{ml}$ of distilled water). After mixing, the solution was allowed to stand for $5 \mathrm{~min}$ and filtered. Two $\mathrm{ml}$ of the filtrate was added to $8 \mathrm{ml}$ of phosphate solution $\left(0.3 \mathrm{M} \mathrm{Na}_{2} \mathrm{HP} 04\right.$ in distilled water) followed by $1 \mathrm{ml}$ of DTNB solution ( $0.04 \% 5$, 5' diothiobis 2-nitrobenzoic acid). The O.D. was measured at $412 \mathrm{~nm}$. Blank was prepared by substituting the sample with water and following the entire procedure as for test. A standard curve was calibrated with freshly 
prepared GSH solution from which the sample values were calculated and expressed as mgs of GSH/gm of tissue protein or as mgs of GSH/dl of erythrocytes.

DETERMINATION OF SERUM CERULOPASMIN: The method followed was essentially that of Henry et al ${ }^{9}$. To the blank, $1 \mathrm{ml}$ of sodium azide reagent ( $0.1 \%$ in $0.1 \mathrm{M}$ acetate buffer, $\mathrm{pH} 6.0$ ), 1 $\mathrm{ml}$ of acetate buffer $(0.1 \mathrm{M}, \mathrm{pH} 6.0)$ and $1 \mathrm{ml}$ of PPD reagent $(0.25 \% \mathrm{p}$-phenylene diamine in 0.1 $\mathrm{M}$ acetate buffer) were added. To the test, $2 \mathrm{ml}$ of the acetate buffer and $1 \mathrm{ml}$ of PPD reagent were added. The tubes were incubated at $37^{\circ} \mathrm{C}$ for $5 \mathrm{~min}$ in the dark. Then $0.1 \mathrm{ml}$ serum (or tissue homogenate $10 \% \mathrm{~W} / \mathrm{V}$ in $10 \mathrm{mM}$ Potassium Phosphate buffer, $\mathrm{pH}$ 7.4) were added to both test as well as blank and mixed. The absorbance of the test against blank were read $10 \mathrm{~min}$ and again $40 \mathrm{~min}$ after the addition of the sample. The formula used for the calculation of the results is given below.

Mgs of ceruloplasmin $/ \mathrm{dl}$ serum $=\mathrm{A}_{40} \mathrm{~min}-\mathrm{A}_{10} \mathrm{~min} \times 1000 \times$ 0.06.In the case of liver homogenates, the values were expressed as mgs of ceruloplasmin /gm protein.

ESTIMATION OF PROTEIN: Protein estimation in the tissue homogenates was done by the method of Lowry et a ${ }^{10}$. Data were expressed as Mean $\pm \mathrm{SE}$ and the significance of difference was assessed by the student's t test.

RESULTS: Table 1 summarizes the effect of i.p. administration of DDC $1.2 \mathrm{gm} / \mathrm{kg}$ body wt on glutathione reductase activity in liver and RBC's of rats at different intervals. The maximum decrease was about $40 \%$ and $56 \%$ respectively, in liver and erythrocytes at $12 \mathrm{hrs}$.

The GSH content of liver and erythrocytes of DDC treated rats was markedly lowered at 6 and $12 \mathrm{hrs}$ after the injection of DDC with a stimulatory effect at $24^{\text {th }} \mathrm{hr}$ in liver but not in erythrocytes (Table 2). Highest decrease (about 71\%) was found both at 6 and 12 hrsin liverafter the administration of an equivalent dose of DDC to the rats.

The effect of DDC administration on ceruloplasmin content of rat liver and serum is presented in Table 3. The level of ceruloplasmin was significantly lowered at the various periods with a gradual return to the control level in $48 \mathrm{hrs}$. DDC had an almost immediate effect on liver ceruloplasmin with a decrease to about 35\% in $1 \mathrm{hr}$ whereas the decrease at this period was not so apparent in the sera of DDC treated rats as compared to the controls. Significant diminution of ceruloplasmin level was seen in the liver and sera, even $48 \mathrm{hrs}$ after the injection of DDC.

Table-1: Glutathione reductase activity of tissues from rats injected with diethyldithiocarbamate $(1.2 \mathrm{gm} / \mathrm{kg}$, in saline, i.p.). Rats were sacrificed at different intervals of time as indicated in column 1. (Results are Mean \pm SD of 6 rats from each group).

\begin{tabular}{|c|c|c|c|c|}
\hline \multirow{2}{*}{$\begin{array}{l}\text { Hrs after DDC } \\
\text { injection }\end{array}$} & \multicolumn{4}{|c|}{ Glutathione reductase activity } \\
\cline { 2 - 5 } & Activity & \% decrease & Activity & $\%$ decrease \\
\cline { 2 - 5 } & $59.1 \pm 5.8$ & - & $61.8 \pm 7.4$ & - \\
\hline Control $^{\text {a }}$ & $47.8 \pm 5.1$ & $19.1^{* *}$ & $51.6 \pm 6.3$ & $16.5^{*}$ \\
\hline 1 & $44.5 \pm 5.0$ & $24.7^{* * *}$ & $34.3 \pm 5.1$ & $44.5^{* * *}$ \\
\hline 6 & $35.7 \pm 4.3$ & $39.6^{* * *}$ & $27.4 \pm 3.8$ & $55.7^{* * *}$ \\
\hline 12 & $39.0 \pm 4.6$ & $34.0^{* * *}$ & $38.7 \pm 4.0$ & $37.4^{* * *}$ \\
\hline 24 & $52.5 \pm 5.1$ & $11.2^{\#}$ & $56.6 \pm 4.7$ & $8.4^{*}$ \\
\hline 48 & & &
\end{tabular}


Control a rats received injections of the saline vehicle. An enzyme unit is defined as $\mathrm{n}$ moles of NADPH oxidized per min per mg protein. ${ }^{* *} P<0.001,{ }^{* *} P<0.01,{ }^{*} P<0.05$, ${ }^{*}$ NS (Not Significant).

Table-2: Reduced glutathione content of tissues from rats injected with diethyldithiocarbamate $(1.2 \mathrm{gm} / \mathrm{kg}$, in saline, i.p.). Rats were sacrificed at various intervals of time after the injection as given in column 1 (Mean \pm SD of 6 rats from each group)

\begin{tabular}{|c|c|c|c|c|}
\hline \multirow{2}{*}{$\begin{array}{l}\text { Hrs after DDC } \\
\text { injection }\end{array}$} & \multicolumn{4}{|c|}{ GSH Content } \\
\cline { 2 - 5 } & \multicolumn{2}{|c|}{ Liver } & \multicolumn{2}{c|}{ Red blood cells } \\
\cline { 2 - 5 } & mgs/gm protein & \% change & mgs/100 ml & $\%$ decrease \\
\hline Control a $^{\text {ayyyy}}$ & $4.5 \pm 0.7$ & - & $60.1 \pm 8.6$ & - \\
\hline 1 & $3.6 \pm 0.7$ & $-20.0^{\#}$ & $53.5 \pm 5.1$ & $11.0^{\#}$ \\
\hline 6 & $1.3 \pm 0.7$ & $-71.1^{* * *}$ & $47.1 \pm 6.4$ & $21.6^{*}$ \\
\hline 12 & $1.3 \pm 0.5$ & $-71.1^{* * *}$ & $37.3 \pm 6.6$ & $37.4^{* * *}$ \\
\hline 24 & $5.4 \pm 0.7$ & $+20.0^{*}$ & $57.3 \pm 6.9$ & $4.7^{\#}$ \\
\hline 48 & $4.9 \pm 1.0$ & $+8.9^{*}$ & $59.9 \pm 7.3$ & $0.3^{\#}$ \\
\hline
\end{tabular}

a Control rats received injections of saline vehicle. ${ }^{* * *} P<0.001,{ }^{* *} P<0.01,{ }^{*} P<0.05$, \#NS (Not significant)

Table-3: Ceruloplasmin content of tissues from rats injected with diethyldithiocarbamate (1.2 $\mathrm{gm} / \mathrm{kg}$, in saline, i.p.). Rats were sacrificed at different intervals as given in column 1 . The results are the Mean \pm SD of 6 rats from each group.

\begin{tabular}{|c|c|c|c|c|}
\hline \multirow{2}{*}{$\begin{array}{l}\text { Hrs after DDC } \\
\text { injection }\end{array}$} & \multicolumn{4}{|c|}{ Ceruloplasmin Content } \\
\cline { 2 - 5 } & \multicolumn{3}{|c|}{ Liver } & \multicolumn{2}{c|}{ Red blood cells } \\
\cline { 2 - 5 } & mgs/gm protein & $\%$ change & mgs/100 ml & $\%$ decrease \\
\hline Control a $^{*}$ & $9.9 \pm 2.0$ & - & $24.9 \pm 4.7$ & - \\
\hline 1 & $6.4 \pm 1.2$ & $35.4^{* *}$ & $20.2 \pm 4.2$ & $18.9^{\#}$ \\
\hline 6 & $5.7 \pm 1.5$ & $42.4^{* * *}$ & $47.1 \pm 3.2$ & $21.6^{*}$ \\
\hline 12 & $4.3 \pm 1.5$ & $56.6^{* * *}$ & $11.4 \pm 3.2$ & $54.2^{* * *}$ \\
\hline 24 & $6.9 \pm 1.0$ & $30.3^{* *}$ & $18.4 \pm 2.4$ & $26.1^{*}$ \\
\hline 48 & $7.2 \pm 1.0$ & $27.3^{*}$ & $20.0 \pm 2.4$ & $19.7^{*}$ \\
\hline
\end{tabular}

a Control rats received injections of saline vehicle. ${ }^{* * *} P<0.001,{ }^{* *} P<0.01$,

${ }^{*} P<0.05$, \#NS (Not Significant).

DISCUSSION: It is believed that GSH is one of the important protective factors against the oxidative damage. It may act not only as a scavenger by itself but also through the GSH dependent enzymes ${ }^{11}$. GSH depletion or inhibition of GSH-GSSG redox cycle has been found to sensitize the cells to an imposed oxidative stress ${ }^{12}$. The decreased level of GSH in the tissues and erythrocytes of DDC treated rats might be related to the level of glutathione reductase, since the function of this enzyme is mainly to keep the glutathione in the reduced state ${ }^{13}$.The results of our present study confirm the earlier reports of Goldstein et $\mathrm{al}^{14}$.

The major factor contributing to the diminished serum ceruloplasmin levels appears to be the copper chelating property of DDC. Al-Timimi and Dormandy ${ }^{15}$ have demonstrated that 
copper is essential for the antioxidant action of ceruloplasmin and that the copper-free apoprotein is ineffective.

The decrease in the level of SOD in the tissue of rats treated with DDC occur almost immediately after the administration of DDC ${ }^{1}$ and the decrease of other antioxidant enzymes such as se-dependent Glutathione peroxidase ${ }^{3}$ and glutathione reductase was seen at a later stage, possibly due to the inefficient elimination of $\mathrm{O}_{2}$ - leading to the inactivation of GSHpx and Glutathione reductase and hence decreased level of GSH.

The present study concludes that glutathione reductase, reduced glutathione and ceruloplasmin are decreased when rats are subjected to oxidative stress on administration of diethyldithiocarbamate.

\section{REFERENCES:}

1. Heikkila RE, Cabbat FS, Cohen G. In vivo inhibition of superoxide dismutase in mice by diethyldithiocarbamate. J Biol Chem. 1976; 251: 2182-2185.

2. Goldstein BD, Rozen MG, Quintavalla JC, Amoruso MA. A decrease in mouse lung and liver glutathione peroxidase activity and potentiation of the lethal effects of ozone and paraquat by superoxide dismutase inhibitor diethyldiothiocarbamate. Biochem Pharmacol. 1974; 28: 27-30.

3. Ramachandra Prabhu H. In vivo inhibition of selenium dependent glutathione peroxidase and superoxide dismutase in rats by diethyldithiocarbamate. Ind J of Exp Biology. 2002; 40:258-261.

4. Fridovich I. Superoxide radical and superoxide dismutases. Annu Rev Biochem. 1995; 64: 97-112.

5. Tyler DD. Role of superoxide radicals in lipid peroxidation of intracellular membranes. FEBS Lett. 1975; 79: 180-183.

6. Bartosz G, Fried R, Grzelinska E, Leyko W. Effect of hyperoxide radicals on bovine erythrocyte membrane. Eur J Biochem. 1977; 73: 261-264.

7. Horn H D, Burns FH. Methods of enzymatic analysis. (ed. Bergmeyer HV) Academic Press, N Y. 1978 pp 875-879.

8. Beutler E, Duron 0, Kelly B M. Improved method for the determination of blood glutathione. J Lab Clin Med. 1963; 51: 882-888.

9. Henry RJ, Chiamori N, Jacobs SL, Segalor N. Determination of ceruloplasmin oxidase in serum. Proc Soc Exp Biol. 1960; 104: 620-624.

10. Lowry OH, Rosebrough NJ, Farr AL, Randall R. J. Protein measurement with the Folin phenol reagent. J Biol Chem. 1951; 193: 265-275.

11. Nagasaka Y, Fujii S, Kanekot. Microsomal glutathione-dependent protection against lipid peroxidation acts through a factor other than glutathione peroxidase and glutathione S transferase in rat liver. Arch Biochem Biophys. 1989; 274: 82-86.

12. Miccadei S, Kyle M E, Gilfor D, Farber J L. Toxic consequences of the abrupt depletion of glutathione in cultured rat hepatocytes. Arch Biochem Biopghys. 1988; 265: 311-320.

13. Williams C H Jr. The Enzymes, $3^{\text {rd }}$ ed. Boyer PD(editors) Academic Press, New York: 1976. p 89-172.

14. Goldstein B D, Rozen M G, Quintavalla JC, Amoruso MA. Decrease in mouse lung and liver glutathione peroxidase activity and potentiation of the lethal effects of ozone and 
paraquat by the superoxide dismutase inhibitor diethyldithiocarbamate. Biochem Pharmac.1979; 28: 27-30.

15. Al-Timini D J, Dormandy T.L. The inhibition of lipid autoxidation by human ceruloplasmin. Biochem J. 1977; 168: 283-288. 